SUSUNAN REDAKTUR PELAKSANA

Ketua Pelaksana

Wakil Ketua

Sekretaris 1

Sekretaris 2

Bendahara

Kopi Editor 1

Kopi Editor 2

Seksi Percetakan 1

Seksi Percetakan 2

Seksi Distribusi 1

Seksi Distribusi 2

Seksi Korespondensi 1

Seksi Korespondensi 2
: Ir. Endro Wahju Tjahjono

: Iwan Setiadi,MT

: Dyah Kusuma Dewi, MT

: Ihwan Haryono, Msi.

: Era Restu Finalis,ST

: Dr. Eko Syamsuddin H.,M.Eng

: Ir. Soegeng Hardjono,MSc.

: Drs. Agus Krisnowo,MT

: Eka Febriyanti,ST

: Ir. Sayuti Syamsuar,MT

: Siti Yubaidah,MT

: Linda Nuryanti,Skom

: Mohammad Ivan,ST 


\section{UCAPAN TERIMA KASIH}

Ucapan terima kasih dan penghargaan disampaikan kepada para pakar yang telah diundang sebagai Mitra Bestari/Penelaah oleh Majalah Pengkajian Industri dalam Volume 9, No. 2, Tahun 2015. Berikut ini daftar nama pakar yang berpartisipasi :

\begin{tabular}{|l|l|}
\hline Nama & Alamat/Instansi \\
\hline $\begin{array}{l}\text { Iwan Hidayat, Ir. } \\
\text { (Specialist Avionics and Navigation) }\end{array}$ & $\begin{array}{l}\text { Gedung Flight Test Center, PT.Dirgantara } \\
\text { Indonesia } \\
\text { Jl.Pajajaran No. 154 Bandung }\end{array}$ \\
\hline $\begin{array}{l}\text { Agus Suhartono, H.Dr.Ing.Ir. } \\
\text { (Bid.Material) }\end{array}$ & $\begin{array}{l}\text { B2TKS, Kawasan Puspiptek, } \\
\text { Gedung 220 Kawasan PUSPIPTEK, Serpong, } \\
\text { Tangerang, Banten }\end{array}$ \\
\hline $\begin{array}{l}\text { Derajat, Drs. } \\
\text { (Bid.Flight Test Engineering) }\end{array}$ & $\begin{array}{l}\text { Gedung Flight Test Center, PT.Dirgantara } \\
\text { Indonesia } \\
\text { Jl.Pajajaran No. 154 Bandung }\end{array}$ \\
\hline $\begin{array}{l}\text { Prof. Dr. Kuncoro Diharjo,ST.,MT } \\
\text { (Bidang Teknik Mesin) }\end{array}$ & $\begin{array}{l}\text { Dekan Fakultas Teknik UNS, Solo } \\
\text { Jl. Ir. Sutami 36A. Ketintang Surakarta }\end{array}$ \\
\hline $\begin{array}{l}\text { Mainizarwan Mel, Dr., MSc } \\
\text { (Bid. Bio Process Engineering) }\end{array}$ & $\begin{array}{l}\text { Engineering Industrial Training Unit, Kulliyah of } \\
\text { Engineering, IIUM Gombak, 53100 Kuala } \\
\text { Lumpur }\end{array}$ \\
\hline $\begin{array}{l}\text { Dr. Indrayati } \\
\text { (Bid.Teknik Sipil Transportasi) }\end{array}$ & Fakultas Teknik Sipil \\
\hline
\end{tabular}




\section{Kata Pengantar}

Majalah Pengkajian Industri Volume 9 No. 2 Agustus 2015 merupakan edisi dengan topik Industri Teknologi Transportasi. Teknologi transportasi selama ini terus dikembangkan baik berupa sarana maupun prasarana, karena adanya peningkatan tuntutan kebutuhan akan pemindahan manusia dan barang yang aman, nyaman dan cepat. Banyak penelitian dan kajian yang dilakukan oleh berbagai pihak baik berupa lembaga maupun perorangan yang bertujuan untuk memenuhi tuntutan tersebut. Pada Majalah IImiah Pengkajian Industri edisi kali ini memuat beberapa penelitian dan kajian menarik mengenai industri transportasi terutama pengembangan kawasan timur Indonesia diantaranya adalah : Pengembangan Klaster Industri Perkapalan untuk Meningkatkan Daya Saing Industri Perkapalan Indonesia dan Pengembangan Klaster Industri Perkapalan untuk Meningkatkan Daya Saing Industri Perkapalan Indonesia.

Pada terbitan ini juga ditampilkan topik yang terkait analisis mengenai keselamatan kereta api di Indonesia yaitu, Patahnya Pegas ulir Kereta Api Akibat Kelebihan Beban, Analisis Pergerakan Kereta Rel Listrik untuk Disain Sistem Keselamatan Kereta Api Otomatis dan suatu Pendekatan Pemodelan "diagram Fundamental Polinomial" untuk Ruas Jalan Bebas Hambatan

Semoga pembahasan pada terbitan ini bermanfaat bagi perkembangan industri transportasi sehingga mampu menjadi industri yang unggul dengan didukung oleh sumber daya yang produktif. Diharapkan juga informasi ini akan menjadi bagian dalam perkembangan penelitian dan kerekayasaan lebih lanjut.

Redaksi selalu berusaha melakukan perbaikan-perbaikan dalam rangka meningkatkan mutu Majalah Pengkajian Industri. Selanjutnya redaksi berencana menerbitkan Vol. 9 No. 3 bulan Desember 2015 dengan Topik "Industri Teknologi Hankam dan Material". Redaksi sangat mengharapkan adanya kritik dan saran yang sifatnya membangun. 


\section{Majalah Pengkajian Industri}

- Patahnya Pegas ulir Kereta Api Akibat Kelebihan Beban

$59-66$ The Breaking of Train Spring Coil Caused by Overweight, M.N. Setia Nusa

- Pengembangan Klaster Industri Perkapalan untuk Meningkatkan Daya Saing Industri Perkapalan Indonesia

The Development of Shipping Industry Clusters for Increasing Compettiveness of National Shipping Industry, Sudirman Habibie, M. Dikdik Gumelar, Rudy Sitorus

- Pendekatan Pemodelan "diagram Fundamental Polinomial" untuk Ruas Jalan Bebas Hambatan.

Modeling Approach of "Polinomial Fundamental Diagram" for Free Way Segments, Mulyadi Sinung Harjono dan Wimpie Agoeng Noegroho Aspar

- Analisis Pergerakan Kereta Rel Listrik untuk Disain Sistem Keselamatan Kereta Api Otomatis.

Analysis of Electric rail Train Movements for Automatic Train Protection System Design, Syamsul Kamar

- Kajian Penentuan Jenis dan Ukuran Sarana Angkutan Batubara dari Pelabuhan Sorong ke PLTU.

Study for Type and Tonnage of Sea Transportation Means of Port on Coal Power Plant Sorong to PLTU, Sjafril karana 